\title{
Motivation and Learning Achievement of Social Science Material on Defending Independence Through Jigsaw Cooperative Learning Model in Punggul 1 Elementary School Gedangan Sidoarjo
}

\author{
Yani Nurhayani \\ State University of Surabaya \\ Surabaya \\ yaninurhayani16070855145@mhs.unesa.ac.id
}

\begin{abstract}
A learning process which rigid and monotonous can reduce students' interest and motivation. If it is done continuously, students become less motivated in learning. It will also affect their learning achievement. [1]. This situation also occurred in class V of Punggul 1 Elementary school, especially in social science learning about defending Indonesian independence. Based on the interviews with class V teachers of Punggul 1 Elementary School, the researcher obtained material of social science scores dealing with the material of Maintaining Indonesian Independence last year. From the data, it can be seen that students had not been able to absorb and understand the material optimally. The test results conducted by the teacher as an evaluation of learning, prove that, with KKM score of 75 for social studies subjects, there were 16 students who had not completed the KKM from the total number of 26 students in grade V SDN Punggul 1. From the data, it can be seen that $64 \%$ of students had not yet completed the KKM. It was because students did not actively participate in learning activities. The students feel bored with the ongoing learning. In the end, such phenomena had an impact on students' learning achievement which made it not optimal. Such learning conditions, required a change in the learning model conducted by the teacher to be able to improve motivation and student achievement in a better direction. The formulation of the problem in this study dealt with whether the motivation to study social studies material of the struggle to maintain the independence of the fifth-grade students of Punggul Elementary School 1 Gedangan Sidoarjo can be improved through jigsaw cooperative learning model using VCD media. It was described and explained that the Jigsaw Cooperative Learning model with VCD media was used to increase motivation and learning achievement in social studies material of the struggle to Maintain the Independence of fifth grade students of Punggul Elementary School. This study described and explained that the Jigsaw Cooperative Learning model using VCD media to improve the learning achievement of Social Sciences Material of Struggle to Maintain Independence of fifth grade students SDN Punggul 1 Gedangan Sidoarjo. The subjects of this study were 26 grade V students of SDN Punggul 1. This research was carried out in two cycles, each of which consists of four stages, namely[2] planning, action, observation and reflection. The researcher collected the data t hrough tests, observation of self- learning activities
\end{abstract}

involving the indicators of success of this study. In cycle 1,16 or $61.5 \%$ of students paid attention to the teacher's explanation, 21 or $80.8 \%$ of students felt happy with the use of media in PBM, 10 or $38.5 \%$ students dare to ask the teacher, 19 or $73.1 \%$ of students were enthusiastic in doing assignments, and 12 or $46.2 \%$ of the students responded to the feedback from the teacher during the learning process. The students who had reached KKM were 17 students or $65.4 \%$, while students who had not reached K KM were 9 children or $34.6 \%$. In cycle II, almost all students $(96.7 \%)$ stated that students 'attitudes and their participation in learning were "fun" and all students $(100 \%)$ stated that students' interest in participating in learning activities was "very interested". The students' responses to the improvement of learning increased from $83,3 \%$ (cycle I) to $96.7 \%$ (cycle II), or an increase of $13.4 \%$. It was revealed that the students who had reached KKM were 22 students or as much as $84.6 \%$, and the students who had not achieved as much as were 4 children or $15.4 \%$.

Keywords-Motivation, Jigsaw Cooperative Learning Model, Student achievement

\section{INTRODUCTION}

A learning process which rigid and monotonous can reduce students' interest and motivation. If it is done continuously, students become less motivated in learning. It will also affect their learning achievement. [1]. This situation also occurred in class V of Punggul 1 Elementary school, especially in social science learning about defending Indonesian independence. Based on the interviews with class V teachers of Punggul 1 Elementary School, the researcher obtained material of social science scores dealing with the material of Maintaining Indonesian Independence last year. From the data, it can be seen that students had not been able to absorb and understand the material optimally. The test results conducted by the teacher as an evaluation of learning, proved that with a KKM value of 75 for social studies subjects, there are 16 students who had not completed the KKM from 26 students in grade $\mathrm{V}$ 
of SDN Punggul 1. From these data, it appeared that $64 \%$ of students had not yet completed the KKM. It was because the students did not actively participate in the learning activities. The students feel bored with the ongoing learning. In the end, this had an impact on student learning achievement that was not optimal.[3]

Such learning conditions, required a change in the learning model conducted by the teacher to be able to improve motivation and student achievement in a better direction. The formulation of the problem in this study dealt with whether the motivation to study social studies material of the struggle to maintain the independence of the fifth-grade students of Punggul Elementary School 1 Gedangan Sidoarjo can be improved through jigsaw cooperative learning model using VCD media.

It was described and explained that the Jigsaw Cooperative Learning model with VCD media was used to increase motivation and learning achievement in social studies material of the struggle to Maintain the Independence of fifth grade students of Punggul Elementary School.

This study described and explained that the Jigsaw Cooperative Learning model using VCD media to improve the learning achievement of Social Sciences Material of Struggle to Maintain Independence of fifth grade students SDN Punggul 1 Gedangan Sidoarjo.

\section{METHOD}

This study used classroom action research (CAR) methods, which is a research carried out by the teacher professionals in their own class through the results of self-reflection as a follow- up to problem solving that occurs in class. It aimed at improving the learning process to be better and could find the most appropriate solution in solving the problems faced in the classroom so that the student's competency developed rapidly and the learning was more passionate.[5]

The followings are some stages of research in conducting classroom action research that will be passed and used to carry out an action research.
a. Research design,
b. Subject, Location and Time of Research,
c. Data Collection Techniques,
d. Data analysis technique.

\section{A. Research Design}

The research design covers stage 1 of reflection (feedback of students after following a series of learning processes), stage 2 of planning improvement process problems that will be carried out in the research process, stage 3 observation actions (during the repair process or solutions in research as well as observations about everything what happened during the action process through the solution in this case the use of jigsaw in social science learning material about defending nation to protect independence), and stage 4 of reflection on the activities that occurred when the action took place for further action.

\section{B. Sub-Section, Location and Time of Research \\ 1. Research Subject}

The subjects for this study were class V of SDN Punggul 1 Gedangan Sidoarjo which consisted of 11 female students and 15 male students. The subjects also involved faculty researcher and observer in the class of students who are interested in studying grade V of Punggul 1 Elementary school. The class was used as the subject of research because the class had an average score under the KKM which had been determined in the standard of contents and standard of process in the basic competency of maintaining Indonesian independence.

\section{Location of Research}

The research was conducted at SDN Punggul I Gedangan Sidoarjo. Sidoarjo, was located in an easily accessible position. Punggul I Elementary School Gedangan Sidoarjo Regency was located on the side of the Punggul village traffic road. Here are the direction: North: river and highway, south: village, home of RT 6 RW I Punggul village, west: village, RT 6 RW I resident of Punggul village, and east: village, RT 6 RW I village, Punggul village.

\section{Research Time}

The study was carried out on August 2018 when the research was held on time according to the semester program and the standard content program and the standards of process that have been set.

\section{Description of the Plan for Each Cycle}

\section{Cycle I}

a. From the results of the initial Reflections on data and interviews

b. Plan

After holding observation or observation of the students that aimed at identifying problems - that occur in the field, and the urgent problems to be solved. It should be based on level of priorities and continued by doing the action of planning and the other following steps. After that, the next one is determining $\mathrm{KD}$ by looking at the standard of content, specifying the method and the learning model used. In this research, Jigsaw learning model with writing learning steps was used.

\section{c. Reflection}

From the results of monitoring and research in cycle 1, the researchers made conclusions. The expected activities, motivation, student learning outcomes could be improved and be better than before. Therefore, there was an improvement in the following cycle and there would be improvements again because the results of learning achievement were considered successful but what was expected was still has not been reached because there are still many students who had not been completed.

The revised design (improved) was based on the reflection (feedback) from the observations done by the researchers to make improvement plans in the next cycle. 
Cycle II

\section{Cycle 1 Reflection Results:}

In constructing the next cycle that dealing with the result of the first cycle reflection, some things that need to be fixed.

\section{Planning}

The second cycle of the theme remains the same but there were several alternative actions that needed be done so that the completeness criteria could be achieved well. Motivation and student achievement increased in action, namely: Teacher performance is optimized in Jigsaw learning and guiding students so the motivation and the achievement increased. Therefore, the students were more enthusiastic in learning using the jigsaw for the students. They were also given a quiz for students that it has higher value if it was given a gift of a star reward to students. Giving support and motivation made the learning more interesting and more active. In addition, providing feedback to turn back and talk about the material struggle to defend independence was a more interesting way.

\section{Implementation and Observation}

The implementation of the teacher acted according to the same action in the previous cycle. Additional activity was that the teacher brings students to talk about the material struggle to maintain Indonesian independence.

It is important to provide information and explanations about media and learning models, so students are ready and focused on the learning process.

\section{Reflection}

The activities in the second cycle were observed and the results were defined to be analyzed and then what improvements were made if most of the students had increased motivation and achievement, they were considered to have achieved minimum competence, then the instructor model suitable to the struggle to maintain Indonesian independence.

\section{Data Collection Techniques}

Some methods were used in a research process for data collection processes [6]In collecting data, many formats and instruments are used and data collection techniques are actually the same as evaluation tools because the point is to obtain data about the state of something measured by a predetermined standard or measure, because evaluating activities also means measuring [7]

From the explanation above, the data collection used by researchers were:

\section{1. observation}

Observation is a method of gathering information for observation in the object of research [6] Observations consist of 2 types, namely direct observation and indirect observation

\section{2.test}

According to [6], test is a set of questions or questions in the form of exercises and other forms of tools that are used to measure various competencies, among others: cognitive abilities, skills, intelligence, abilities or talents possessed by individuals or groups.

In the process this study is used data collection techniques in the form of test techniques.

The written test used was to provide an overview of the abilities and competencies of students in social science learning material dealing with the struggle for depending the independence.

\section{E. Data Analysis Techniques}

This study used descriptive statistics that would provide a description and description of all the characteristics and symptoms of the study. According to Yatim Riyanto (2001: 104), a very critical step in the analysis of research data, whether statistical or non-statistical analysis should be considered by researchers.

Student achievement in learning in analysis by utilizing the percentage calculation of learning completeness with the formula:

$$
\mathbf{p}=\frac{\sum \text { siswa yang tuntas belajar }(f)}{\sum_{\text {siswa }(N)}} \times 100 \%
$$

Source: Classroom Action Research (Aqib, 2009: 41). Description:

p: Percentage of student learning achievement f: Frequency of students who had completed intervals $\mathrm{N}$ : Number of all students

To calculate the class average value, the formula was used:

$$
\bar{x}=\frac{\Sigma X}{N}
$$

Source: Classroom Action Research [8]

$$
\text { Information: }
$$

$\bar{x} \quad=$ Average of student score

$\sum X=$ The sum of all student values in the research

$\mathrm{N}=$ Number of students involved in the research followup process. The learning achievement was analyzed by utilizing references dealing with students' comprehension or mastery of competencies. The level of students' understanding of competence was ensured by calculating the percentage of scale 5 .

The basic determination with calculation of percentage in Ska la Lima is explained as follows:

Table 3.1 Determination of benchmarks with Percentage Calculations for Scale 5 


\begin{tabular}{|c|l|}
\hline $\begin{array}{c}\text { Percentage of mastery } \\
\text { level }\end{array}$ & Learning Achievement Criteria \\
\hline $85 \%-100 \%$ & Very satisfactory \\
\hline $75 \%-84 \%$ & satisfying \\
\hline $60 \%-74 \%$ & Good enough \\
\hline $40 \%-59 \%$ & Less satisfactory \\
\hline $0 \%-39 \%$ & Failed / unsuccessful \\
\hline
\end{tabular}

Check out students' motivation data

Assessment as data material in the implementation of the learning process was evaluated based on the average score in the implementation of the learning process carried out by researchers. The data from the observations of students' motivation, during the learning process was analyzed using the following formula:

$$
P=f / N X 100 \%
$$

\section{INFORMATION;}

$\mathrm{P} \quad=$ percentage

$\mathrm{f} \quad=$ A lot of motivation is fulfilled

$\mathrm{P} \quad=$ percentage

$\mathrm{N} \quad=$ Total number of motivations assessed [9]

Motivation assessment criteria as follows:

$$
\begin{array}{ll}
0 \%-19 \% & =\text { Very Low } \\
20 \%-39 \% & =\text { Low } \\
40 \%-59 \% & =\text { Medium } \\
60 \%-79 \% & =\text { High } \\
80 \%-100 \% & =\text { Very High }
\end{array}
$$

\section{RESULTS AND DISCUSSION}

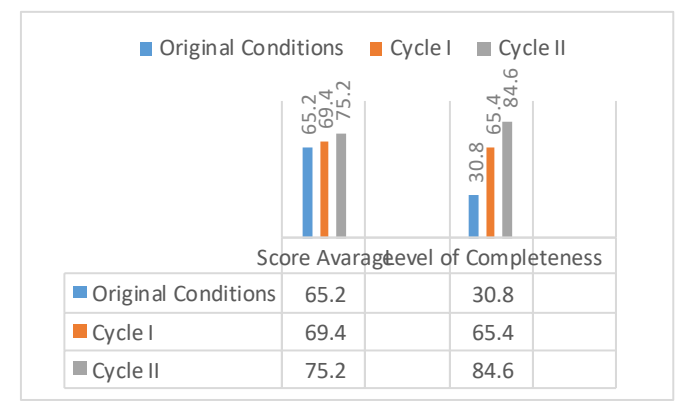

Graph 4. 3 Average score and learning completeness level in Cycle I and Cycle II

The development of material related to the struggle to maintain independence in cycle I and cycle II based on the interval of mastery level. Such result can be seen in the following table 4.10.

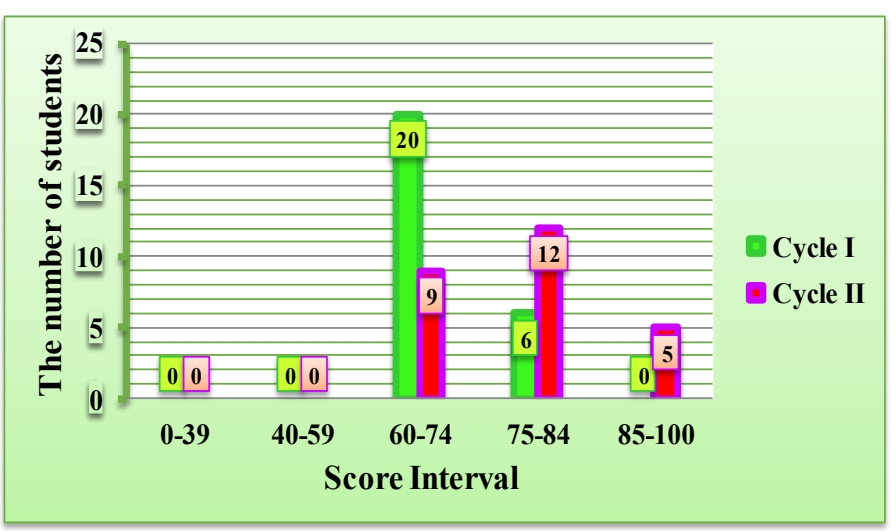

Graph 4. 4 Development of Student Social Science Learning Achievement Based on Mastery Level Intervals

Based on the data that has been presented above, it can be seen that the social studies learning achievement was in good category. Thus, it can be concluded that the use of Jigsaw cooperative learning model with VCD media could improve social science learning achievement of the students in class V of SDN Punggull students.

This study also revealed the actions done during the use of Jigsaw cooperative learning model with VCD media. There were impacts including: (1) the use of the use of the VCD Jigsaw type cooperative learning model could motivate students to be more active in learning. It could be seen from the enthusiasm of the students in participating in learning, (2) it could motivate the students to be active, creative, and enthusiastic in writing stories. It could be seen in active group activities (3) the classroom atmosphere was alive, therefore, PAKEM was achieved.

Although the results of cycle I and cycle II had shown an increase in social studies learning achievement and the achievement of the KKM, there were still 4 students who had not reached the KKM. The four children were students who had not been able to write smoothly. Although they had been given special guidance and motivation to be able to write smoothly, it seemed that they still had not succeeded yet. The four children needed more attention from the teacher in the next learning.

\section{RESEARCH DISCUSSION}

From the data that had been elaborated and explained previously, the elaboration and explanation through discussion of classroom action research resulted the titile " Improving Fifth Graders' Motivation and Learning Achievement of Social Science Material on Defending Independence Through Jigsaw Cooperative Learning Model in Punggul 1 Elementary School Gedangan Sidoarjo. All the indicators had been fulfilled the requirements in a classroom action research. The details were elaborated as follows:

\section{A. Learning Implementation}


It showed that in the use of the Jigsaw type learning model by the teacher in the first cycle only reached ten aspects/components carried out or $71.4 \%$, and the average total of $71.8 \%$. Among all aspects/components of using learning the Jigsaw cooperative learning model above, there were several aspects/components that have not yet emerged.

The teacher's explanation became increasingly difficult for students to understand, because the teacher's explanation of the subject matter was less heard throughout the class. Meanwhile, in the organization, the teacher did not adjust the material after the student completeed the Jigsaw type learning model. The questions that the teacher gave were never appeared because the students were not directly involved in summing up the results of group work. The results of the observations above were supported by the results of the students' responses to learning improvement, especially regarding the use of Jigsaw cooperative learning models that provided unfavorable or unhappy responses $(28.2 \%)$

It showed that all aspects/ components in the use of the Jigsaw cooperative learning model by the teacher appeared and are carried out in the improvement of cycle II. In preparation for learning using LKS or students' worksheet, the teacher could generate students' motivation to learn. The teacher's explanation became easily understood by students, because the teacher's explanation of the subject matter had been heard by all members of the class. Meanwhile, in organizing the teacher has given material stabilization after the students had finished using the Jigsaw cooperative learning model with group discussion method. The feedback had been done optimally, therefore, the teacher and students concluded the results of the group discussions. Therefore, the process of teaching and learning by using group discussion methods was optimal $(100 \%)$.

\section{B. Motivating students}

Here, it can be concluded that the dominant activity of students in the first cycle was feeling happy with the use of the Jigsaw cooperative learning model with VCD media in the learning process. The following data can be taken in table 4.4, in which 16 or $61.5 \%$ of students paid attention to the teacher's explanation, 21 or $80.8 \%$ of students felt happy with the use of media in PBM, 10 or $38.5 \%$ of students dared to ask the teacher, 19 or $73.1 \%$ of students were enthusiastic in doing assignments, and 12 or $46.2 \%$ of students responded to the teacher's feedback during the learning process.

It can be concluded that the motivation activities increased since the students in cycle II were happy with the use of Jigsaw cooperative learning model with VCD media dealing with the students' enthusiasm in doing assignments increased. The following data could be taken in table 4.8 that is, 20 or $76.9 \%$ of students paid attention to the teacher's explanation, 23 or $88.5 \%$ of students felt happy with the use of media in PBM, 18 or $69.2 \%$ of students dared to ask the teacher, 23 or $88.5 \%$ of students were enthusiastic in carrying out assignments, and 17 or $65.4 \%$ of students responded to the teacher's feedback during PBM.

\section{Student Learning Achievements}

It can be seen that the average score of social studies learning achievement on the material about the struggle to maintain independence in the initial conditions was 65.2 and in the first cycle, it reached 69.4 which means that there was an increase of 4.2; from the first cycle of 69.4 to the second cycle of 75.2, there was an increase in the average score of mastery ability of the struggle to maintain independence of 5.8. The achievement of the level of completeness of learning from KKM in the initial conditions was $30.8 \%$ to the first cycle of $65.4 \%$. There was an increase of $34.6 \%$ and from the first cycle of $65.4 \%$ to the second cycle of $84.6 \%$, there was an increase of $19.2 \%$.

The explanation above proved that Jigsaw cooperative learning method using VCD media could increase the motivation and learning achievement of social science material related to the struggle to maintain independence for fifth grade students of Punggull Elementary School. It was in line with Ririt's research (2017) showing the use of VCD type with Jigsaw cooperative learning model could increase the motivation and student learning achievement. In addition, this learning model could also develop better things such as respecting opinions between friends, collaborating that could improving character education, improving abilities to think in high level to solve problems and to implement the knowledge and skills.

Based on the theory of cones, Edgar Dale's experience ( Cone of Experience ) chooses a Jigsaw cooperative learning learning model with VCD media because according to Edgar Dale, a range of levels of experience from being directed to experience through communication symbols, which was stretched from the concrete to the abstract, Based on the results of the discussion in the study, it could be concluded that the Jigsaw Cooperative learning model with VCD media could be applied in social science learning dealing with the matetial of the struggle to defend independence for fifth year students of SDN Punggul1, Gedangan District, Sidoarjo Regency.

\section{CONCUSION}

1). The use of the Jigsaw ratified Coope approach with VCD media could improve the mastery of the material about maintaining Indonesian Independence in the Social Studies subject and Interest of the fifth graders of Punggul 1 State Elementary School Gedangan Sidoarjo. The highest value achieved by students reaches 100 and the class average value was 80.0 .

2). Student motivation activities and Student responses to this learning improvement increased from $83.3 \%$ (cycle I) to $96.7 \%$ (cycle II), or an increase of $13.4 \%$.

3) Student achievement increased with achievement of completeness learning level from KKM at initial conditions of $30,8 \%$ to cycle I by $65.4 \%$ there was an increase of $34.6 \%$ and from cycle I by $65.4 \%$ to cycle II by $84,6 \%$ there was an increase of $19.2 \%$. 
4). The use of Jigsaw Cooperative Learning Model with VCD Media was able to improve student learning achievement on ways to maintain Indonesian Independence in social studies subjects and can increase motivation in fifth grade students of Punggul 1 Gedangan Sidoarjo Elementary School. Among the 26 students, only 4 students scored below 75 as the minimum level of learning completeness.

\section{REFERENCES}

[1] A. Arsyad, "Media pembelajaran." Jakarta: PT Raja Grafindo Persada, 2011.

[2] R. E. Slavin, "Cooperative learning teori, riset dan praktik," Bandung Nusa Media, vol. 236, 2005.

[3] D. W. Johnson and R. T. Johnson, "Making cooperative learning work," Theory Pract., vol. 38, no. 2, pp. 67-73, 1999.

[4] S. Sharan, "Handbook of Cooperative Learning: Inovasi pengajaran dan pembelajaran untuk memacu keberhasilan siswa di kelas," Yogyakarta. Imperium, 2009.

[5] Sugiyono, Metode penelitian pendidikan:(pendekatan kuantitatif, kualitatif dan $R$ \& D). Alfabeta, 2008.

[6] Y. Riyanto, "Paradigma baru pembelajaran," Jakarta: Kencana, 2010

[7] S. Arikunto and S. Suhardjono, "Penelitian tindakan kelas." Jakarta: Bumi Aksara, 2006.

[8] E. T. Stringer, Action research in education. Pearson Prentice Hall Upper Saddle River, NJ, 2008.

[9] N. Sudjana, "Supervisi Pendidikan Konsep dan Aplikasinya Bagi Pengawas Sekolah," Bekasi Binamitra Publ., 2011. 